\title{
The Effect of the Storytelling Method Using Bigbook on the Language Ability of Children Aged 5-6 Years in Group B TK Mutiara Bunda Bangkinang
}

\author{
Nelti Rizka
}

Early Childhood Education Department, Padang State University, Padang, Indonesia, neltrizka@ gmail.com

\begin{abstract}
The ability of early childhood language is a very important thing because with the language the child can communicate with friends or people around him. But the problems that often occur now that speech and language delay experienced by 5-8\% preschool children. At the age of 5 years, $19 \%$ of the children identified had speech and language disorders. The purpose of this study is to determine the effect of the storytelling method using big book on the ability to express the child Language. This research uses pre-experimental type with one group pretest-posttest design. The study was conducted on 5-6 years old students in Group B TK Mutiara Bunda Bangkinang Kota in November 2018. Data analysis techniques used paired t-test. Result of comperative analysis between pretest value with posttest ability to express child language at significant level 0,05 obtained t count equal to $-17,515$ and sig value equal to 0.000 , can be concluded that there is influence of storytelling method using big book to ability express child early child language. It is expected that kindergarten teachers can apply the Story telling method using big book in improving the ability to express the child Language.
\end{abstract}

Keywords: Language, Storytelling, Big Book, Early Childhood

\section{INTRODUCTION}

Children's language ability is very important because with this language child can communicate with friends or people around them. Language development consists of the ability to speak, listen, read and write. The potential for language can be stimulated through active communication using good and correct language. Language acquisition as a communication tool must go through a separate development stage. Speaking is the most important communication tool, so it has a role in intellectual, social and emotional development. In childhood, children gradually change from communicating with just sounds like: laughing, crying, then communicating with movements such as: nodding, shaking their heads (Kurniawati Yanti and Sri Setyowati, 2014)

According to the Ministry of National Education (2001) the function of language development for children early age is as a tool to communicate with the environment, as a tool to develop children's intellectual abilities, as a tool to develop children's expression, as a tool to express feelings and fruits of thought to others. Readiness of children to interact with adults means the development of their understanding of the rules and functions of language with adults will provide a relationship with the concept, in this case the child will get the experience of learning about language from the environment around him by imitating the language style of the adults around him as well. Therefore, language skills in early childhood and after adolescence will greatly depend on the acquisition of language skills acquired since childhood, it will produce success in future language (Santrock, 2007)

One of the problems that often occur today is many early children experience language disorders or delays. Speech and language delays are experienced by $5-8 \%$ of preschool age children. Nearly $20 \%$ of children aged 2 years have impaired speech and language disorders. At the age of 5 years, $19 \%$ of children were identified as having speech and language disorders $(6.4 \%$ speech impairment, $4.6 \%$ speech and language weakness, and 6\% language weakness). Developmental disorders that are often complained of parents is delay in talking. However, children with speech and language disorders are late getting attention. Seeing such a large impact arising from language delays in preschoolers, it is very important to optimize the process of language development in this period (Soebadi, 2013).

The conditions occurring in the field, namely in the Kindergarten (TK) Mother Bunda Bangkinang city during the past three years also indicate that many children experience speech impairment. Every year there are always children who experience speech. Seeing these conditions, it is very important to do a method to stimulate language development in early childhood, especially in expressing language through the method of storytelling using media big book. 
According to Permendikbud No.137 of 2014, Level of Achievement of Children 5-6 Years Old Development in Expressing Language that is able to answer more complex questions, mention groups of images that have the same sound communicating verbally, have vocabulary, and recognize symbols for preparation for reading, writing and arithmetic, composing simple sentences in complete structure (main sentence-predicate description), having more words to express ideas to others, continuing some of the stories / tales that have been played and showing understanding of the concepts in the storybook .

Each child has a different pace and rhythm of development, but in general have the same stages of development. Learning PAUD, educators need to provide activities that are appropriate to the stages of child development, and provide support in accordance with the development of each child. For this reason, the importance of educators understanding the stages of child development. In addition, the use of various media and learning resources is also important for development so that children can explore with objects in the surrounding environment. Children who are accustomed to using nature and the environment for learning, will develop more sensitivity to awareness to care for the environment (Suryana et al, 2015).

Optimizing children's development can be done by stimulating children's abilities according to their age. One way to stimulate language skills of early childhood is to use the method of storytelling, namely how to deliver learning material orally in the form of stories to children. Storytelling has been promoted to develop language ability (Putri \& Ardi, 2013) by using digital storytelling. By using the method of storytelling, it can train the ability to absorb, capture power, think power of children, power of concentration of children, imagination of children, and help the development of children's language in communication disrupt social interactions. Stories with pictures can attract children to talk. Colors and images are the main attraction of children. With the focus of attention on children, will affect the cognitive abilities so that children will be better to remember and continue the development of the language properly (Suyanto, 2003).

One of the media that can be used to tell early children is to use Big Book, which is a picture book that is chosen to be raised, has special characteristics of the enlargement of text and images. This is intentionally done so that shared reading occurs between the teacher and student or parents and children. This book has special characteristics that are colorful, attractive images, and words that can be repeated, have predictable plots, and have rhythmic text patterns to be sung, Fitrian \& Cahyo (2014) in Madyawati (2016). The use of Big Book story media can develop children's basic abilities in all aspects of language, especially in aspects of speech development (expressing children's language), for example by means of teachers stimulating children's comments about the content of images or stories in the Big Book, besides that there are also activities to discuss and tell stories back to the story in the Big Book so that it can hone children's language development especially in expressing language.
Considering the importance of language skills for early childhood and the problems that have been stated above, the writer can formulate a research problem that is there is the effect of the method of storytelling using a bigbook on the ability to express the language of children aged 5-6 years in Group B of Mutiara Bunda Bangkinang City Kindergarten.

In this globalization era, a study of the "Most littered Nation In the World" conducted by Central Connecticut State University, Indonesia was ranked 60th out of 61 countries regarding interest in reading (Gewati, 2016). Indonesian people's habits in reading and writing is relatively low, the condition is very alarming. Referring to the UNESCO survey in 2011 showed that the index level reading Indonesian people is only 0.001 percent. This means that there is only one person out of 1000 residents who still want to read the book seriously. Thus it should be maximal in growing and improving the reading culture of Indonesian society. Starting from multiply reading, both at school and at home, to the provision of infrastructure such as the supply of books to read.

The book become a means of intelligence, many people become smart and rich because of reading. Therefore, the habit of reading should be introduced to children at an early age. Every child should be introduced to the reading so that they quickly mastered the language and proficient in reading (Permatasari, 2016) In connection with the child, there are pros and cons to read and write at an early age children. Various studies and supports the idea that children under 7 years of age allowed to learn calistung, and other studies have different opinions that not to learn calistung. The reason contra aligned with the research of child development psychologist from Switzerland, Jean Piaget as outlined by Afin Murtie on his calistung Teach Children to Play. He stated that the future of children cannot yet concrete operational thinking. Children become overburdened and the original purpose of educating children into a dilemma because even children become unhappy and could not enjoy their lives. In fact, the opinion of its own Piaget caused confusion for parents and teachers who want to develop their intellectual potential without having to wait for ages 7 years. One can imagine how children it difficult to follow the lessons when they enter elementary school (Bimba Aiueo, 2013) These days in Indonesia, several elementary schools requires the students to be able o read and write as a requirements of New Students Admission (NSA), the reading and writing becoming units that must be resolved by children under seven years (Early Childhood) (Eprilia \& Prasetyarini, 2011). Piaget's opinion of its own cause confusion for parents and teachers who want to develop their intellectual potential without having to wait for ages 7 years. One can imagine how children it difficult to follow the lessons when they enter elementary school (Bimba Aiueo, 2013).

Early childhood education is focused on finalizing the students emotionally, socially, and cognitively to be able to follow the process of learning in Primary Schools (Ruhaena, 2015). Kemendikbud asked the Kindergarten's teachers not to burden their students learn to read and write 
as well as at the primary level. Director of ECCE Kemendikbud, Ella R. Yulaelawati Ph.D states that "Helping children to enrich their language through play is recommended compares to imposing the children to read without the child knows its meaning. The method is not classically ". Ella added that, learning in early childhood was not like learning in elementary school classrooms, where teachers dictate the child to write or read, for children at an early age should be learning in a fun way and not leave the burden. Besides Ella also states that "The point that can be done is to teach more vocabularies, storytelling, reading books through creative expressive not flat reading". In line with Ella, Chairman of the Association of Teachers and Education Personnel in Early Childhood (HIMPAUDI) Prof. Netty Herath said that early childhood should be taught to read and count solely on the stages, it is included in an activity called with literacy (Aji, 2015).

Literacy is one of the areas of academic skills which most important because it affects the acquisition of skills in other academic fields. Good literacy skills can broaden the horizons of knowledge, inspire or even solutions open up many new opportunities. Results of research by Senechal \& LeFreve show that good early literacy skills help children to learn and read easier and improve children's success in school (Ruhaena, 2014, p.1). Additionally, Allington states that children's early literacy skills may predict later literacy skills at moderate to high level (Trehearne, 2011, p.34). Children who have mastered the literacy skills early will cause the child to be a good learner throughout his life.

Activities that take advantage of multimedia technologies will further support literacy learning process, as it integrates text with images, animations and sounds. It is very interesting for children because getting through many senses sensory stimulus, not only see and hear it. Multimedia multisensoris able memfungsi more receptors that inputs that go to the brain becomes more powerful and facilitate the process of information coming into the brain. In addition, the multimedia technology, helped children to understand more quickly the things that are abstract because it can be presented more concrete.

Multimedia is one factor of many factors that have the most impact in the growth, development of psychological and behavioral changes in all ages, especially children. Responding to the influence of multimedia technology to the development of such children, educators must know in advance about the substance of multimedia technologies and able to be part of them. That is, do not stutter technology, and of the knowledge of the educators are able to maximize the positive and minimize the step by step can be negative impacts.

Multimedia learning promises great potential for changing the way a person to learn, to obtain information, customize information and so on, and also provides an opportunity for educators to develop learning techniques so as to produce maximum results. Likewise, for learners with learning multimedia educational purposes would be quickly achieved with a strategy to absorb information quickly and efficiently, resources are no longer focused on the text of a book solely but broader than that. Growing awareness of the importance of the development of multimedia learning must be realized by educators, especially the availability of support from the technology.

Multimedia learning is a form of technology that can be used as an alternative medium of learning. The use of multimedia can stimulate and enhance student motivation in learning. The influx of multimedia in learning to create a fun atmosphere in the study for multimedia combines some elements of the media so that the learning process by using multimedia more attractive. According Warsita (2008) defines that multimedia interactive learning can be defined as a combination of various media were packed (programmed) in an integrated and interactive way to deliver a message specific learning. The relationship between the message and the media, the media here act as a message (Fero, 2011).

Multimedia learning can be developed on the assumption that the communication in the learning process will be more meaningful, because it is a combination of multimedia learning various media elements that consist of text, graphics, photographs, animations, video and sound are presented interactively in instructional media. Multimedia regarded as a medium of teaching and learning are attractive based on its ability to touch the various senses: sight, hearing and touch (Ramli, 2013, p.57). It becomes a good alternative as a tool for teaching and learning.

With the multimedia technology in literacy learning will make the learning process more interesting, for example in terms of appearance combined with some images or animations. The attractiveness of the physical appearance greatly affect the learning process, the more attractive multimedia display, the students are more motivated to learn, thus affecting the results of their study (Resiani, 2015). The beauty, the attractiveness and their interactivity in a medium of learning is a means that learners are not boring in following the lessons and the greatest effects are expected to be motivated learners and make it easier to accept the subject matter (Fanny, 2013). It is clear that the use of multimedia technology in teaching can be accepted on the basis of self-learning process and enhance the active role of students (CBSA).

Results of an initial interview conducted by researchers for 15 kindergarten teachers in kindergarten Sabbihisma shows that there is still confusion experienced by teachers in the use of multimedia technology in a positive way in the process of learning in kindergarten. There are no clear guidelines and examples of how to use multimedia technology was performed in learning, particularly in literacy learning of children. Whereas the use of multimedia technology is now a critical factor in the implementation of learning in the era of industrial revolution 4.0.

TK Sabbihisma is a kindergarten that uses multimedia technology in the development of the literacy skills of children. The curriculum used in learning in kindergarten curriculum 2013 Sabbihisma is combined with information technology-based learning. Nearly 50\% 
of learning in kindergarten using multimedia technology. The use of multimedia technology in teaching literacy in kindergarten, can be a model for other kindergartens in the city of Padang. Therefore, research into the use of multimedia technology literacy learning in kindergarten Sabbihisma worth doing.

\section{RESEARCH METHODS}

This research is a type of quantitative research using pre-experimental methods. The design used in this study was a one group pretest-posttest, in this design the treatment was given without the control class (Sugiyono, 2013).

Pre-test IntervensiPost-test

Experiment

Group

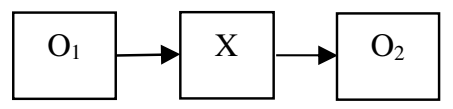

In this research design the researcher made initial observations to find out the child's early ability to express language. Furthermore, children are given treatment in the form of the application of the method of storytelling using the media bigbook. After the treatment is carried out, the researcher then conducts the final observation.

The study was conducted in Group B of Kindergarten Mutiara Bunda Bangkinang city 6-30 November 2018. Research subjects were students aged 5-6 years in Group B of Mutiara Bunda Bangkinang Kindergarten, with 15 children, consisting of 7 boys and 8 daughters.

Data collection in this study uses the method of observation or observation. According to Arikunto (2002), in using the observation method, the most effective way is to complete it with an observation format or blank as an instrument. observation sheets Pretest and posttest compiled in the form of seven indicators of child development achievement reveal the language of children aged 5-6 years in accordance with Permendikbud No.137 of 2014. Scores are given 1 if not yet developed (BB), 2 if starting to develop (MB), 3 if it develops as expected (BSH) and 4 if it develops very well (BSB). The total score is divided according to the number of indicators and the average value of the children's language is grouped into 3 categories as follows:

Table 1. Indicators and the average value of the children's language

\begin{tabular}{|c|c|}
\hline Mean & Category \\
\hline $1-2$ & Enough \\
\hline $2,1-3$ & Good \\
\hline $3,1-4$ & Very Good \\
\hline
\end{tabular}

Data Analysis Techniques use the data normality test and hypothesis test. Data normality test uses the ShapiroWilk formula, because the sample is small $(\leq 50)$, it is said to be normal data if the significance value $(\mathrm{P})>0.05$. After that, if the data is normal, then testing the hypothesis using a parametric statistical t-test (Dahlan, 2013).
To determine the significance of the influence of independent variables, namely the method of storytelling (X) on the dependent variable, namely the ability to express the language ( $\mathrm{Y}$ ) of children aged 5-6 years by comparing the initial state (before being treated) and the final state (after being treated), so it can be known whether existing allegations can be accepted or rejected. To test this hypothesis a paired t-test is used if the normality test results are normal, but if the data are abnormal then the Wilcoxon test uses the Mann Whitney U test.

\section{RESEARCH RESULTS}

After collecting data in accordance with the procedures that have been described, then the next step is the presentation of data and research results in accordance with the results of observations, the following results of the average value revealed language that has been done by researchers as follows:

Table 2. Pretest and Post Test

\begin{tabular}{|c|c|c|}
\hline Number & Pre-test & Post-test \\
\hline 1 & 1,43 & 3,29 \\
\hline 2 & 1,71 & 3,14 \\
\hline 3 & 1,86 & 2,71 \\
\hline 4 & 1,86 & 3,00 \\
\hline 5 & 1,57 & 3,43 \\
\hline 6 & 2,14 & 3,43 \\
\hline 7 & 1,71 & 2,86 \\
\hline 8 & 2,29 & 3,43 \\
\hline 9 & 1,71 & 2,86 \\
\hline 10 & 1,86 & 3,57 \\
\hline 11 & 1,71 & 3,43 \\
\hline 12 & 1,71 & 3,14 \\
\hline 13 & 1,57 & 3,29 \\
\hline 14 & 1,57 & 3,29 \\
\hline 15 & 2,14 & 3,43 \\
\hline
\end{tabular}

Table 3 . The category

\begin{tabular}{|c|c|c|c|c|}
\hline \multirow{2}{*}{ Category } & \multicolumn{2}{|c|}{ Pre-test } & \multicolumn{2}{c|}{ Post-test } \\
\cline { 2 - 5 } & F & \% & F & \% \\
\hline Enough & 12 & 80 & 0 & 0 \\
\hline Good & 3 & 20 & 4 & 27 \\
\hline Very Good & 0 & 0 & 11 & 73 \\
\hline Total & 15 & 100 & 15 & 100 \\
\hline
\end{tabular}

Data normality test using the Shapiro-Wilk formula shows that the significance value $(\mathrm{P})>0.05$ so that it can be concluded that the data is normally distributed.

Table 4. Data Normality Test Results Table

\begin{tabular}{|c|r|r|r|}
\hline \multirow{2}{*}{} & \multicolumn{3}{|c|}{ Shapiro-Wilk } \\
\cline { 2 - 4 } & Statistic & Df & \multicolumn{1}{c|}{ Sig. } \\
\hline Pretest & .909 & 15 & .130 \\
\hline Posttest & .900 & 15 & .096 \\
\hline
\end{tabular}

Based on the results of the normality of normally distributed data test, the hypothesis test used is a paired $t$ test and the following results are obtained: 
Table 5. The Effects of Storytelling Methods Using Bigbooks to Reveal Children's Language Capabilities 5-6 Years

\begin{tabular}{|c|c|c|r|r|}
\hline & $\boldsymbol{N}$ & Mean & \multicolumn{1}{|c|}{$\boldsymbol{t}_{\text {hitung }}$} & P value \\
\hline Pre test & 15 & 1,79 & - & .000 \\
\hline Post test & 15 & 3,22 & 17.515 & \\
\hline
\end{tabular}

\section{DISCUSSION}

The results showed that before the method of storytelling most of the children 12 people $(80 \%)$ had the ability to express the language in the category quite well and after the application of the method of storytelling usingmedia, bigbook it can be seen the ability to express children's language increased to an excellent category of 11 children $(73 \%)$.

After testing normality normal distribution of data is known and continues to test the hypothesis using a paired t-test and the results obtaine $\mathrm{d}_{\mathrm{t}}-17515$ and a $\mathrm{P}$ value of 0.000 means that there is significant influence storytelling method using bigbook to the ability to express language in children aged 5-6 years Mutiara Bunda Bangkinang Kindergarten.

The method of storytelling using themedia Big Book can help children to further develop the ability to express language, because this media has large-sized text and images and colorful images that are in accordance with children's thinking at the pre operational stage, namely symbolic thinking. This media is made according to the needs in developing language skills in children. Media storytelling in concrete form can help to develop language skills in children. His activities also did not escape the element of fun and play so that in the end learning to read and express language is not scary and creepy, but it is a fun thing for children.

The story presented for children aged 4-6 years, of course, must be in accordance with the world of their lives. The contents of the story must be sourced from everyday experiences that may be experienced or simple things that are easily digested by the stages of thinking. The purpose of the method of storytelling for children aged 4-6 years is so that children are able to listen carefully to what is conveyed by others, children will ask if he does not understand it, will be able to answer questions, children can tell and express what they hear and tell to others, so that the wisdom of the contents of the story can be understood and gradually heard, observed, implemented, and told to others, according to Tampubolon (in Nurkhasanah Umi, 2016) "Storytelling has a big influence on the development of children's language skills".

The results of this study are supported by theories that reveal that themedia Big Book can change students' physical mentality in learning to express language so that children are more excited and feel easier. It is recommended for parents / educators should try to use Big Book media as a variety of media activities so that children do not feel bored and bored. This large designed book helps children to focus more on images and text. While reading the story parents / educators can demonstrate what they read in the picture and point to every word that is read. Ideally, Big Book should be of at least A3 or A2 size.
By using thismedia Big Book parents / educators can be an example for children how to read letters, words and sentences correctly. Children learn how to pronounce words correctly and understand certain intonations and expectations. The experience of language activities played by parents / educators in a conducive atmosphere will encourage children to actively participate (Madyawati Lilis, 2016).

This study is also in line with the results of research by Kurniawati Yanti (2014) which states that the use of big book media can improve speaking skills in children. In this action research there was an increase in the ability to speak in children who were shown in cycle I and cycle II. In the first cycle of the first meeting the average speaking ability was reached by $25 \%$ and at the 2 nd meeting the average score was $30 \%$. While in the second cycle of meeting 1 the average score of speaking ability achieved by $50 \%$ and at meeting 2 reached $80 \%$. This proves that through the big book media increases the ability to speak early childhood.

\section{CONCLUSION}

Methods of telling stories usingmedia book big influence on the ability to express language of children aged 5-6 years with the results oft the $^{-17515}$ and a $P$ value of 0.000 . The method of storytelling that uses bigbook thishas large-sized text and images and colorful images that are in accordance with children's thoughts at the preoperational stage, namely symbolic thinking. This media is made according to the needs in developing language skills in children. It is expected that Kindergarten teachers can apply the Storytelling method using a bigbook in improving children's language expression skills.

\section{REFERENCES}

[1] Arikunto,Suharsimi.(2002).Prosedur Penelitian Suatu Pendekatan Praktek. Jakarta: Rineka Cipta.

[2] Dahlan, M.S. (2013). Statistik untuk Kedokteran dan Kesehatan. Jakarta: Salemba Medika

[3] Depdiknas. (2001). Didaktik Metodik di Taman Kanak-Kanak. Jakarta: Depdiknas Dirjen Pendidikan Dasar dan Menengah Dirjen TK

[4] Kurniawati Yanti dan Sri Setyowati. (2014). Meningkatkan Kemampuan Berbicara Anak Melalui Metode Bercerita Dengan Media Big Book Di Ppt Tulip Surabaya. Universitas Negeri Surabaya

[5] Madyawati, Lilis. (2016). Strategi Pengembangan Bahasa Pada Anak. Jakarta: Prenada Group

[6] Nurkhasanah Umi. (2016). Upaya Meningkatkan Kemampuan Mengungkapkan Bahasa Melalui Metode Bercerita Dengan Media Big BookDi Paud Al-Muttaqien Sukabumi Bandar Lampung. Skripsi. FKIP Universitas Lampung 
[7] Permendikbud No.137 Tahun 2014 tentang Standar Nasional Pendidikan Anak Usia Dini.

[8] Putri, R. \& Ardi, H. (2013). Using Digital Storytelling to Teach Speaking at Senior High School. Journal of English Language Teaching, 2 (1), 282-288

[9] Santrock J. (2007). Perkembangan Anak Edisi Kesebelas Jilid I. Jakarta: Penerbit Erlangga

[10] Soebadi. (2013). Keluhan Anak Keterlambatan Bicara. http://idai.or.id/publicarticles/klinik/keluhan-anak/keterlambatanbicara.html. Diakses tanggal 29 November 2017

[11] Solehudin. (2006). Pembaharuan Pendidikan TK. Jakarta: Universitas Terbuka

[12] Sugiyono. (2013). Metode Penelitian Pendidikan. Bandung: Alfabeta

[13] Suryana, D., Elina, E., Nurevi, N., \& Ratnawilis, R. (2015). Model Pembelajaran Berbasis Pendekatan Saintifik pada Taman Kanak-kanak di Kota Padang.
[14] Suyanto Slamet. (2003). Konsep Dasar Pendidikan Anak Usia Dini. Yogyakarta: UNY 